\title{
Understanding the Antecedents of Entrepreneurship and Renewable Energies to Promote the Development of Community Renewable Energy in Rural Areas
}

\author{
Noelia Romero-Castro ${ }^{1, * \mathbb{D}}$, Vanessa Miramontes-Viña ${ }^{2}$ and María Ángeles López-Cabarcos ${ }^{3}$ (D) \\ 1 Department of Finance and Accounting, Faculty of Economics and Business Studies, University of Santiago \\ de Compostela, 15782 Santiago de Compostela, Spain \\ 2 Research Group on Sustainable Value Creation in Organizations, University of Santiago de Compostela, \\ 27002 Lugo, Spain; vanessa.miramontes@usc.es \\ 3 Department of Business Administration, Faculty of Business Administration and Management, University of \\ Santiago de Compostela, 27002 Lugo, Spain; angeles.lopez.cabarcos@usc.es \\ * Correspondence: noe.romero@usc.es
}

check for

updates

Citation: Romero-Castro, N.; Miramontes-Viña, V.; López-

Cabarcos, M.Á. Understanding the Antecedents of Entrepreneurship and Renewable Energies to Promote the Development of Community Renewable Energy in Rural Areas. Sustainability 2022, 14, 1234. https://doi.org/10.3390/ su14031234

Academic Editor: Jianxiong Zhang

Received: 31 December 2021

Accepted: 19 January 2022

Published: 21 January 2022

Publisher's Note: MDPI stays neutral with regard to jurisdictional claims in published maps and institutional affiliations.

Copyright: () 2022 by the authors Licensee MDPI, Basel, Switzerland. This article is an open access article distributed under the terms and conditions of the Creative Commons Attribution (CC BY) license (https:// creativecommons.org/licenses/by/ $4.0 /)$.

\begin{abstract}
Sustainable rural development (SRD) is an essential component of sustainable development on a global scale. Community Renewable Energy (CRE) has been advocated as a step forward in the progress towards SRD. While Northern European countries are experiencing a high development of CRE, Southern European countries lag behind. Considering entrepreneurship and renewable energy technologies (RET) as two fundamental components of CRE, through a systematic literature review this study identifies the antecedents or conditioning factors of entrepreneurship and RET exploitation in rural areas of developed countries, understanding that these same antecedents condition the development of CRE in these countries. The identified factors are organized around five capital spheres: economic, human, social, physical and natural. Given that these five spheres are not watertight compartments, but rather that their limits are diffuse and there are multiple interactions between them, we try to highlight their interrelationships through System Thinking based on the design of causal loop diagrams. The results can help policy makers and CRE projects' promoters in the design of effective policies and strategies to foster the development of CRE in rural areas of developed countries.
\end{abstract}

Keywords: Community Renewable Energy; rural entrepreneurship; renewable energy technologies; systematic literature review; causal-loop diagrams

\section{Introduction}

Sustainable rural development (SRD) has been recognized as of utmost importance to the achievement of global sustainable development [1,2]. Rural areas can make a definitive contribution to the goals related to climate change [3,4] and energy transition [5-7]. Energy decentralization or distributed energy, i.e., the small-scale production of electricity or heat near consumption sites, has been indicated as a necessary step in this energy transition [8], particularly in rural areas $[9,10]$, and renewable energy technologies (RET) have been identified as an optimal source to be exploited under this model [11-13]. Von Bock und Polach et al. [14] recognize that a decentralized supply of renewable energy can positively contribute to SRD.

Achieving SRD in developed countries, especially in the most peripheral and isolated areas, faces challenges related to depopulation and ageing and the limited access to services, markets or human resources [15-18]. An endogenous development model based on a bottom-up approach and the use of local resources for rural areas has been called for, with entrepreneurship being a necessary ingredient [19]. Following Korsgaard et al. [20], a distinction must be made between "entrepreneurship in the rural" and "rural 
entrepreneurship" (RE). The last is intimately committed to the place and to the leverage of local resources, conceived as an activity that is inscribed in its spatial context and is integrated through the use of resources, creating value not only for the entrepreneur but also for the rural context [21].

Both entrepreneurship and RET present distinctive and particular characteristics in urban and rural settings [22-24] and developed and developing countries [25,26] so that $\mathrm{RE}$ and the energy transition of rural areas in developed countries need specific strategies and forms of support policy $[17,27,28]$. However, neither in government policies nor in academic literature has much attention been paid to the role that the RET and RE binomial can play in achieving an SRD.

Energy transition may offer new development opportunities for rural areas, due to the abundance of RET sources (sun, wind, water, biomass) and the availability of land [14,29]. Kitchen and Marsden [3] and Von Bock und Polach et al. [14] consider rural areas as optimal settings in which to promote local development models based on RETs. This can be especially supported through decentralized and community-based forms of RET production, known as Community Renewable Energy (CRE). In fact, in many countries, rural areas are the ideal place for the development of CRE [29]. CRE allows citizens, under alternative legal forms, to become investors, owners, consumers, producers and/or distributors at the same time [30].

The development of CRE has been linked to different factors, but to date a systematic process of identification of all the factors that could be determinant for the development of rural CRE projects has not been carried out. However, there is a large body of academic literature that has studied the determinants of both entrepreneurship and RETs in the rural context of developed countries. Under the assumption that both entrepreneurship and RET converge in CRE initiatives, we suggest that the analysis of this previous literature can improve knowledge about the set of factors that can be significant for the expansion of CRE in rural areas of developed countries.

This study deals with this research question: what are the conditions for the development of CRE projects in rural areas of developed countries? To answer this, a systematic review of the literature (SLR) on entrepreneurship and RET in rural areas of developed countries is carried out. Based on this review several conditioning factors for the development of CRE are identified and organized around five forms of capital (economic, human, social, natural and physical). Our main hypothesis is that all these forms of capital and factors are interrelated both inside and between each form of capital. Based on our SLR, we identify these interrelationships and represent them through causal loop diagrams. This analysis can facilitate the design of policies and strategies to promote CRE among both public authorities and private developers.

The rest of the work is organized as follows: Section 2 presents the conceptual framework under which the five spheres of capital considered are linked to entrepreneurship and the use of RET in rural areas and, ultimately, to the development of CRE and the achievement of SRD. The analytical methods used are then explained, namely an SLR to identify the factors that configure each sphere of capital, and the use of causal loops to collect their interrelationships. Section 4 presents the results of both types of analysis and Section 5 presents a discussion of these. Finally, the implications, limitations and possible extensions of the study are raised.

\section{Conceptual Framework}

CRE can be a key element in the comprehensive management of entrepreneurship and RETs in rural areas and is receiving increasing attention in the academic literature. CRE projects respond to the need to create new business models for a sustainable energy transition and SRD [5] and can be seen as a form of social entrepreneurship [31]. Walker and Devine-Wright [32] highlight that CRE projects can vary from a financial, organizational and legal point of view. The CRE concept includes energy cooperatives that own energy infrastructure, or the co-ownership and co-management of projects by local communities, 
companies and local governments [33-35]. It is important to distinguish between communities of interest and place-based communities [36]. The former are defined by some common goal but do not imply a geographic link. In rural areas, place-based communities should be considered, related to shared values within a particular territory or landscape [37].

Regarding how the previous literature has approached the analysis of CRE projects, van der Schoor and Scholtens [38] identify nine thematic areas: transition studies, science and technology, economics, acceptance, sociology, governance, planning (in general), spatial (planning) and normative (social). However, these areas frequently overlap in CRE studies, reflecting the multidimensional and multi-stakeholder nature of the concept [39].

Various studies have analyzed and classified the antecedents of entrepreneurship and renewable energies around different forms of resources, assets, or forms of capital. Akgün et al. [40] relate rural development to rural capital, as a combination of natural capital (part of the natural environment that can contribute directly or indirectly to human satisfaction), man-made capital (the economic capacities of the physical environment), human capital (size of the working-age population and investment in education and training of people) and social capital (networking, trust, and relationships within communities). Garrod et al. [41] propose the concept of rural capital to frame the economic benefits for rural communities generated through sustainable uses of the rural environment, including natural, physical, and social assets.

Regarding rural economic performance, Agarwal et al. [42] analyze the influence of economic, human and environmental capital, as well as less tangible or soft factors (culture, social capital). Directly concerned with RE, Müller and Korsgaard [43] highlight the importance of specific resources in specific spatial contexts: physical (natural resources, raw materials, infrastructure and landscape), human, social/community (local professional and private alliances with the community and other entrepreneurs in the area, forming small informal business networks and cooperatives), intangibles (cultural, historical and heritage resources such as traditions, cultural amenities, history and historical buildings, legends, images and a distinctive local identity or brand of place), and financial, clients and points of sale/markets (local and non-local). Concerning community entrepreneurship, Borch et al. [44] recognize that different types of human, social, physical and financial resources are combined to form community enterprises in rural municipalities.

Finally, regarding the sustainability and acceptance of RET in rural areas, González et al. [45] relate these to social capital (relationships and social ties between members of a community or group), human capital (skills, knowledge and health), physical capital (infrastructure and technology available to communities to sustain their livelihoods, which determine to what extent human and social capital could increase), natural capital (air and water quality, land and biodiversity) and financial capital (credits, regular inflows of money or transfers from the state, such as pensions).

Based on these contributions, we consider five main forms of capital in rural territories: natural capital, physical capital (infrastructure), social capital (trust, cooperation, networks, social services, attachment to place), human capital (skills, entrepreneurial orientation, population structure) and economic capital (rates and quality of employment, economic structure, population change, business creation or financial resources). Economic capital is related to the financial resources that are involved and mobilized to obtain benefits [42]. Human capital refers to the skills and knowledge that an individual owns in order to be productive [45]. Social capital is directly related to the relationships that arise between people as individuals and society [14]. Physical capital refers to infrastructure and available technology [45]. Finally, natural capital refers to all those renewable and non-renewable resources that can be found in the environment [46]. These five forms of capital bring together various factors that influence the development of entrepreneurship, RET and CRE and that facilitate SRD that reverts again to the five spheres of capital (Figure 1). 


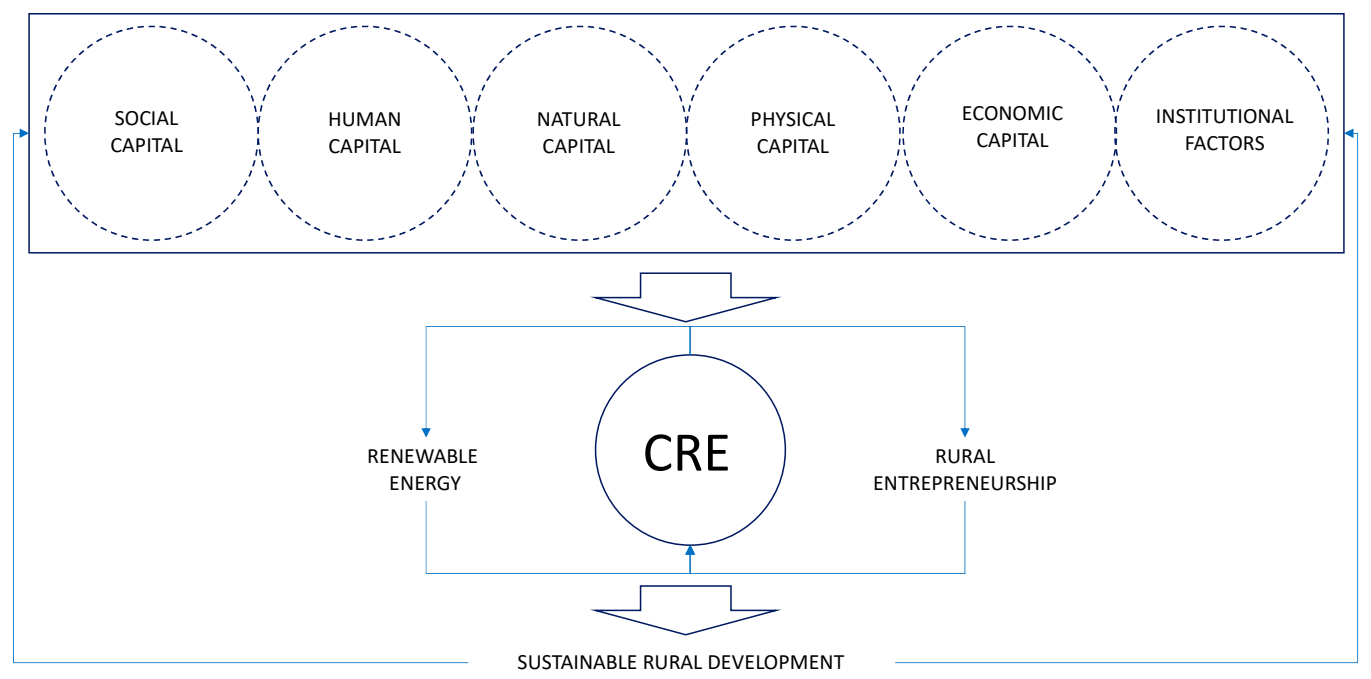

Figure 1. Conceptual framework for the classification of the antecedents of CRE and SRD.

\section{Methods}

To identify and understand the antecedent factors of entrepreneurship and RET in rural areas of developed countries which can be decisive in the promotion and development of CRE initiatives, we apply two research methods. First, we use an SLR to identify in previous scientific contributions which factors have been considered influential in the expansion of entrepreneurship and RET in rural areas of developed countries. Second, we resort to the development of causal loop diagrams to highlight the interrelationships between these factors, which must be considered in the formulation of public policies to promote CRE, and in the design of CRE projects and proposals.

\subsection{Systematic Literature Review}

According to Cook et al. [47], SLRs differ from traditional reviews by using a replicable, scientific and transparent process. An SLR can minimize biases, reduce random effects, and increase the legitimacy of data analysis [48]. All these benefits lead to more reliable results that allow the drawing of conclusions [49].

The Scopus database is chosen, as Adriaanse and Rensleigh [50] indicate that it performs better than Web of Science or Google Scholar in several respects, and covers a wider range of journals and articles than WoS [51]. To compile the literature related to RET and $\mathrm{RE}$, the keywords "rural AND renewable energy" and "rural AND entrepreneurship" are used, including other equivalent terms for each concept (Table 1).

Table 1. Search strings in Scopus.

\begin{tabular}{cc}
\hline Research Field & Search Terms \\
\hline RET & "woodland" OR “village" OR "rural" AND “Renewable energy" OR \\
"sustainable energy" OR "community energy" OR "microgrids" OR \\
"mini-grids" OR "small grids" OR "distributed energy" \\
"woodland" OR "village" OR "rural" AND "new business" OR "new \\
RE & $\begin{array}{c}\text { firms" OR "new ventures" OR "entrepreneurship" OR "entrepreneur" OR } \\
\text { "business creation" OR "self-employment" OR "young firm" OR "spinoff" }\end{array}$ \\
\hline
\end{tabular}

The search was carried out in March 2018 covering all the academic literature published to this date. On the 2036 articles obtained related to RET, and the 2192 related to RE, a first filter was made based on the reading of titles and summaries, selecting only those articles corresponding to developed countries according to the World Bank (Washington, DC, USA) classification. This leaves 231 articles related to RET and 310 related to RE. Subsequently, the content of the articles is reviewed to determine their suitability for the 
objective pursued (identification of conditions), and other reference literature cited in them is consulted (snowballing). This leaves the SLR database made up of 87 articles related to RET and 89 related to RE.

\subsection{Causal-Loop Diagrams}

Once the most relevant antecedents analyzed in the academic literature concerning entrepreneurship and RET in the rural contexts of developed countries have been identified, it is necessary to recognize that all these factors, organized around the five major spheres of capital considered (economic, human, social, natural and physical), interact with each other not only within but also between spheres of capital. We try to formalize these interactions using diagrams of causal relationships. The use of causal-loop diagrams is related to systems thinking [52,53], and both have been advocated as an appropriate way to represent the systematic nature within different human phenomena related to sustainable development [45].

A causal diagram includes variables connected by arrows that represent causal influences or links. One causal-loop diagram is constructed for each type of capital identified in the conceptual framework using the Vensim software, version 8. The identified interrelations were defined in terms of their systemic logic and consistency with the literature. The following notations are used: EC to refer to economic capital, HC for human, SC for social, NC for natural, and PC for physical. Within each capital sphere, each causal relationship, involving one or more factors, is identified with the notation corresponding to that sphere together with correlative numbers, while when identifying relationships between factors of two different capitals, their two notations are used separated by a hyphen, indicating first that corresponding to the sphere of capital in which the causal relationship originates, and also using correlative numbers to identify more than one causal relationship between the same spheres.

On the other hand, and according to the conceptual framework of the study, all the causal diagrams contained in each sphere of capital converge on the same path that links entrepreneurship and RET with CRE and ultimately results in SRD, from which a feedback process is generated again towards the five spheres of capital, understanding that this SRD produces positive impacts on them.

In addition to the five capital spheres, an additional sphere is identified corresponding to Institutional Factors (IF). These have been classified in different ways. Deakins et al. [54] distinguish between public (public policies and institutions) and private (i.e., the impositions of cooperatives on their partners or clients in relation to product or process specifications). The distinction between formal and informal factors is, nevertheless, more common $[29,55]$ and adopted in this study.

\section{Results}

\subsection{Conditioning Factors for the Development of RET and RE}

Figure 2 shows the main descriptive data of the two databases (a detailed list of all the articles included in the SLR can be found in Appendix A). The set of 87 articles on RET covers a period between 1995 and 2018, the oldest article being that of Tyler and Degoey (1995), and the most recent article that by Bauwens and Devine-Wright [56]. The years with the highest number of published articles are 2016 and 2017. The articles dealing with RET in rural areas for high-income countries show an upward trend from 2012 onwards. The journal with the most publications is Energy Policy with a total of 20 articles, followed by Renewable and Sustainable Energy Review with seven articles, and Research on Energy and Social Sciences with six articles. A high percentage of articles (67\%) refer to RET in general or a combination of RETs. Among those that focus on a particular type of RET, those related to wind energy (12\% of the total), bioenergy $(9.6 \%)$ and solar energy $(6 \%)$ stand out. For other RETs such as hydropower, biomass and marine energy, almost no publications were collected. Among the countries more commonly studied is the United Kingdom, with a total of 19 articles, followed by the United States with 11 articles, and finally Germany with eight articles. 

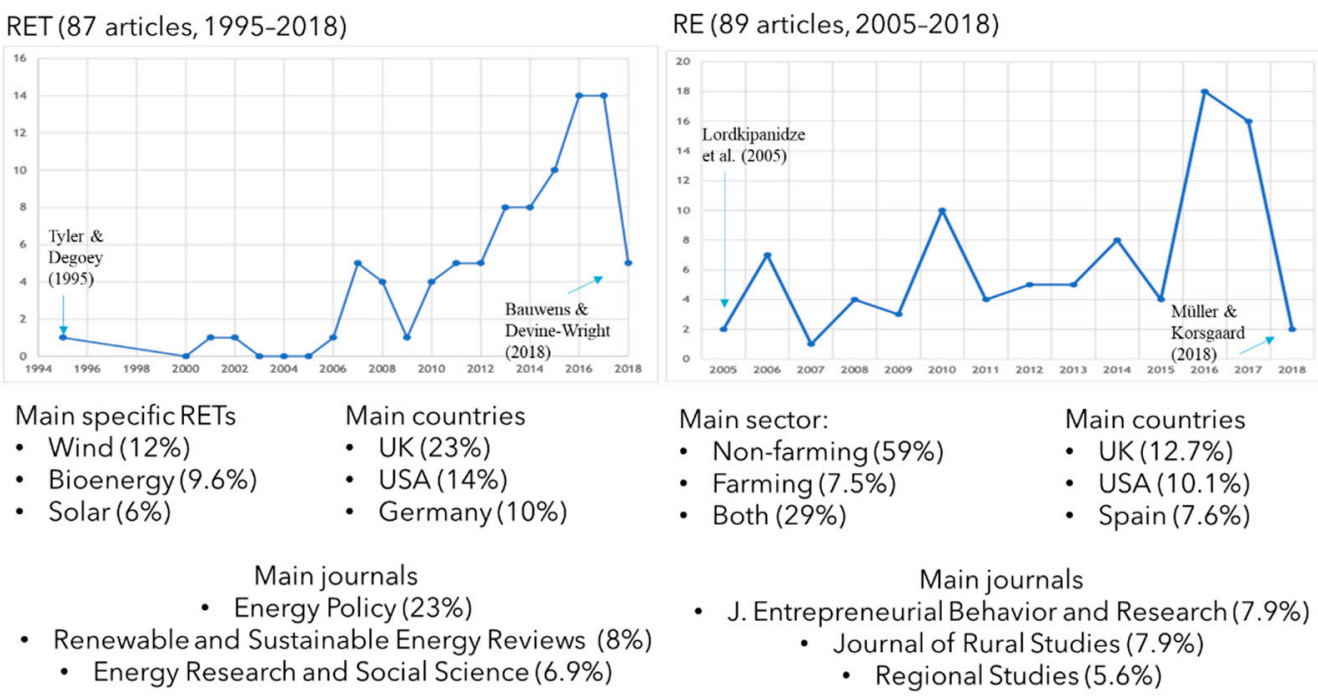

Figure 2. Descriptive data on the set of articles derived from the SLR for RET and RE.

The 89 articles on RE cover the period 2005-2018, the oldest article being the one published by Lordkipanidze et al. [57], and the most recent one that published by Müller and Korsgaard [43]. The years with the highest number of publications were 2016 and 2017, as in the case of RET. The journals with most publications are the International Journal of Entrepreneurial Behavior and Research and the Journal of Rural Studies, with a total of seven articles each, followed by Regional Studies with five articles. A high percentage of the articles (59\%) address business activities that are not related to the agricultural sector, related, for example, to tourism [58-60], or ICT [61,62]. Publications focused on both farm and non-farm activities represent $29 \%$. Articles related solely to farm activities represent $7.5 \%$ of the total. Among the countries with the most articles, three stand out: the United Kingdom, with a total of 12 articles, the United States with 11 publications, and Spain with eight articles.

The reading of the articles allowed the identification of alternative factors that could be considered as antecedents of rural RETs and RE. Table 2 shows the main factors identified within each capital, including the institutional sphere.

Table 2. Conditioning factors of RET and RE identified based on the SLR.

\begin{tabular}{cc}
\hline Capital & Factors \\
\hline Institutional (IF) & $\begin{array}{c}\text { Formal: political (fiscal, economic, energy, territorial, agricultural); non-financial assistance and support programs (training, } \\
\text { orientation and advice, networking), financial support programs (grants, soft loans, guarantees) } \\
\text { Informal: knowledge and innovation networks, clusters, alliances, and public-private partnerships; participatory planning, } \\
\text { management, and ownership processes; local governments involvement; media and social networks }\end{array}$ \\
\hline $\begin{array}{c}\text { Economic Capital } \\
\text { (EC) }\end{array}$ & $\begin{array}{c}\text { Entrepreneurial risk; Funding sources; Access to extra-local markets; Access to local markets/critical mass /local energy } \\
\text { demand; Economic strength; Energy security; Unemployment; Embeddedness; Self-employment; R + D + i/Technological } \\
\text { change; Available income; Competition; Economic feasibility }\end{array}$ \\
\hline $\begin{array}{c}\text { Social Capital (SC) } \\
\text { Human Capital } \\
\text { (HC) }\end{array}$ & $\begin{array}{c}\text { Structures (family, friends); Local entities /local government; Role models; Social services; Cultural and historical heritage; } \\
\text { Customs and lifestyles; Place; Trust; Values and social norms; Networks, alliances, clusters; Place attachment; Bonding SC; } \\
\text { Bridging SC; Linking SC; Social acceptance; Commitment }\end{array}$ \\
\hline $\begin{array}{c}\text { (experience) human capital; Competences and skills (Entrepreneurial skills/creativity, Managerial skills/other related to RE); } \\
\text { Key person/actor; Entrepreneurial orientation (Attitude towards risk, Willingness to invest); Motivations (Entrepreneurship } \\
\text { by necessity, Entrepreneurship by opportunity, Local/social orientation, Lifestyle entrepreneurship, Diversification) }\end{array}$ \\
\hline $\begin{array}{c}\text { Natural Capital } \\
\text { (NC) }\end{array}$ & $\begin{array}{c}\text { Geographic location; Distance to metropolitan centres; Flora and fauna; Biodiversity; Landscape; Geology and soils; Earth; } \\
\text { Air; Water; Space; Potential for renewable energy and other resources or land uses; Countryside Capital; Access to resources; } \\
\text { Resources usable in economic activities }\end{array}$ \\
\hline $\begin{array}{c}\text { Physical Capital } \\
\text { (PC) }\end{array}$ & $\begin{array}{c}\text { Infrastructure (Road network; Telecommunications network; Water supply and sanitation network; Energy supply network; } \\
\text { Waste collection and treatment network) }\end{array}$ \\
\hline
\end{tabular}


4.2. Causal-Loop Diagrams between the Antecedents of RET and RE in Rural Areas of Developed Countries

\subsubsection{Institutional Factors}

Formal and informal institutional factors condition all forms of capital and, in turn, are affected by many of their components (Figure 3). As some examples, while Romich and Bowen-Ellzey [63] explain how public policies and support programs can improve the educational level and the trust and acceptance of wind energy, or González et al. [45] highlight the importance of generating trust through consultation and community participation processes, Meccheri and Pelloni [21] verify that the acceptance of institutional support is conditioned by personal characteristics (sphere of human capital) and social capital, and Jagoda et al. [64] verify that the recourse of rural companies to government support agencies is hampered, among other factors, by the search for autonomy (which is part of entrepreneurial orientation in the HC sphere). Institutional factors have also been identified as determinants of online-startup motivation [65]. Relevant also is the role of public policies that regulate access to the exploitation of natural resources such as soil $[29,66,67]$, agricultural activity [68] or renewable energy resources [11,68], and that of formal and informal institutions in improving knowledge and sensitivity or awareness about the benefits of RETs [45,69-71].

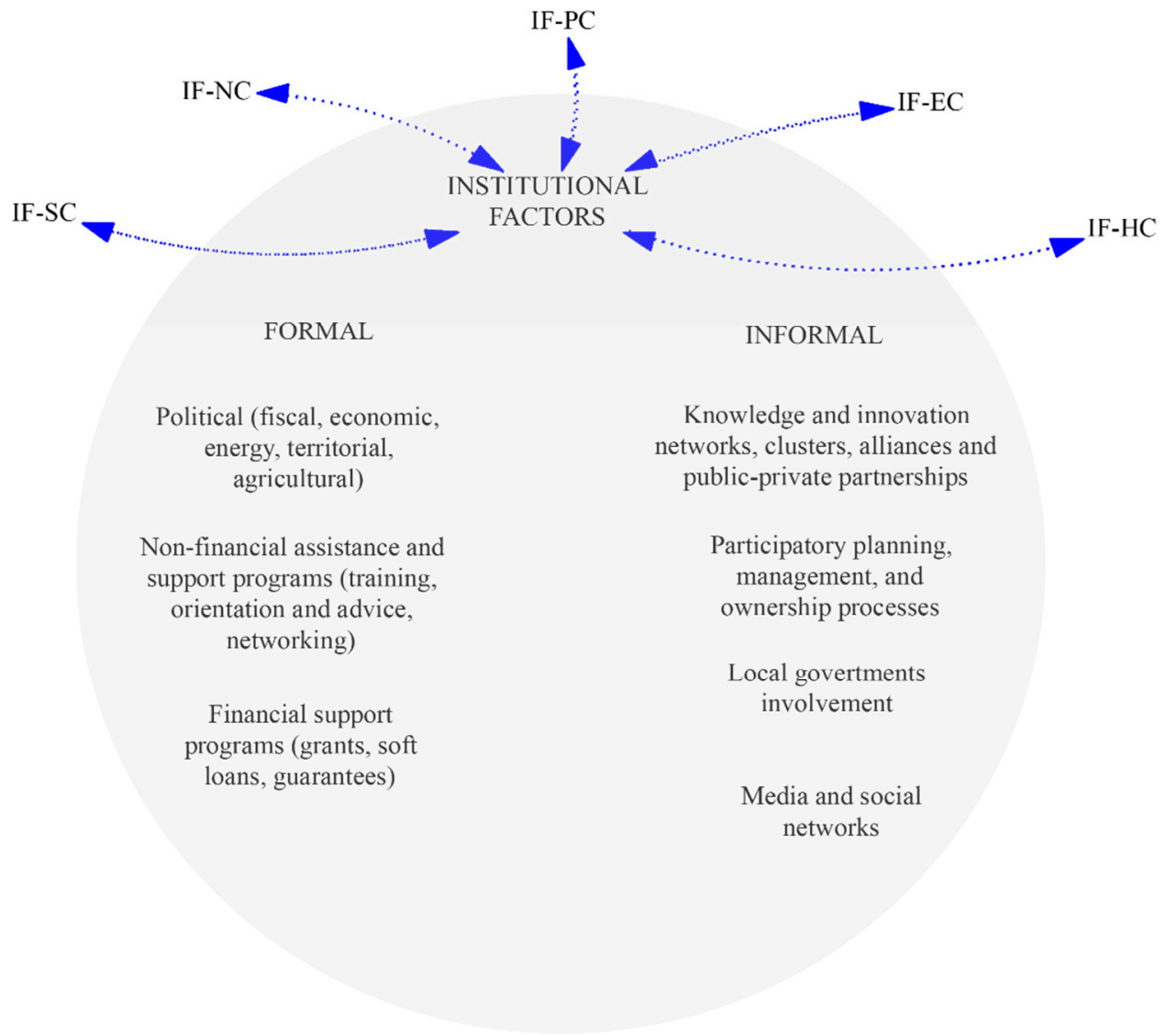

Figure 3. Institutional factors.

Institutional factors also condition the relationship between the development of business activity or the implementation of RET in rural areas and its positive contribution to SRD. The mediating effect of community ownership of RET facilities has been acknowledged to allow an equitable distribution of benefits and a positive socioeconomic impact on the community [72-75]. Obviously, for this to materialize, two conditions are required: that formal and informal institutions allow participation in ownership (scope of institutional factors) and that community members are willing to invest. 


\subsubsection{Economic Capital}

Figure 4 shows the causal relationships between the elements of the EC sphere, as well as those that originate or end in it. Among the former, in a first approximation, the causal-loop EC1 reflects how the risk associated with entrepreneurial activity (which in turn depends on the HC-EC6 relationship) conditions access to funding sources, and this, in turn, affects risk. Meccheri and Pelloni [21] point out that entrepreneurs with a greater accumulation of human capital tend to have less aversion to risk, commit to larger projects and, consequently, are more likely to require external financing. Psaltopoulos et al. [76] also point out the influence of human capital accumulation on the initial capital structure since it affects the entrepreneur's perception of risk. On the other hand, the availability of local financing sources can reduce entrepreneurial risk [76].

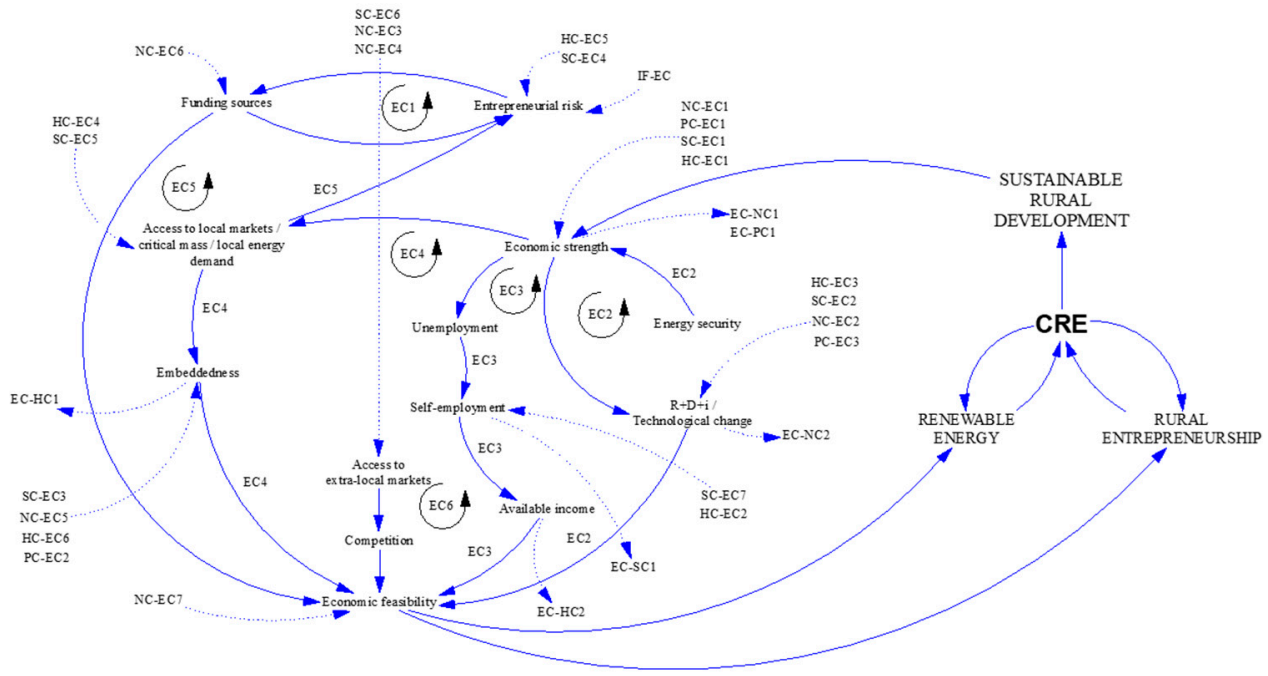

Figure 4. Causal relationships in the EC sphere.

Turning to the EC2 causal-loop, it is proposed that a context of economic growth (sectoral diversification, presence of large companies and great market potential) facilitates R\&D\&I (Olaniyi and Reidolf, 2015) and the settlement in the rural setting of technologybased companies (Lafuente et al., 2010), which can promote new ventures in any sector, including RET, as well as the development of forms of social innovation such as CRE (Magnani et al., 2017; Van der Horst, 2008) or similar innovative business models that contribute to the economic viability of projects (Karlsson et al., 2017). In the case of RET projects, they increase energy security (Angelis-Dimakis et al., 2011; Graziano et al., 2017) which is a pillar of economic development (Wang et al., 2009; Wüste and Schmuck, 2012).

On the other hand, the context of economic growth conditions the evolution of unemployment and self-employment (EC3). Unemployment has been identified as a motivator for self-employment [22,77]. The labor market situation affects available income, which is a determining factor both of the ability to invest in entrepreneurial initiatives [78] and of the local demand capacity [79] and, therefore, of the economic viability of the projects. Economic feasibility facilitates the implementation of entrepreneurship and RET initiatives that contribute to rural development, and this, in turn, leads to economic regeneration [80].

Furthermore, the context of economic growth conditions the critical mass of both population and companies, which shapes the local demand for products and services and, in particular, the local demand for energy, which Graziano et al. [5] identify as necessary for the success of CRE projects (EC4). The existence of a solid local demand (together with the availability of inputs reflected in the NC-EC4 relationship) facilitates the embeddedness of projects, and this is a facilitating factor of entrepreneurial activity even in the face of restrictions in the availability of resources [43]. 
Under the EC5 causal-loop, the configuration of the critical mass of population and companies and their dynamics of change affect the risk of starting a business [79], connecting with EC1, which reflects the interrelation between risk and access to finance. The use of various funding sources has also been found to contribute to the viability and success of projects $[81,82]$.

Finally, in EC6, access to extra-local markets (conditioned by the distance to metropolitan centres (PC-EC2), the availability of natural services to attract, for example, rural tourism (NCEC3), or the existence of bridging capital (SC-EC6)) implies the possibility of increasing economic activity in the extra-local sphere and increasing competition $[83,84]$, affecting the economic feasibility of entrepreneurial initiatives. EC5 + EC6 may be the most appropriate local development formula, combining the best of both worlds (local and extra-local) [85].

Among the impacts that revert to other capital spheres, we highlight the following:

- $\quad$ EC-HC1: Local embeddedness, reflected in the creation of local employment, local trade and local development, contributes to increasing levels of HC (in terms of critical mass) in rural economies [86].

- $\quad$ EC-HC2: Lack of income is a trigger to diversify (through RET, rural tourism, etc.) traditional agricultural activity [74,87-89].

- EC-SC1: Self-employed people are role models that are integrated into the social capital of a community (connects with SC-EC7).

- EC-NC1: The strength of the economy facilitates the preservation of countryside capital.

- EC-NC2: Innovation and the adoption of new technologies facilitate better use of natural resources, such as RET potential [11,13,90,91].

- EC-PC1: The strength of the economy facilitates the provision and adequate maintenance of infrastructures.

\subsubsection{Human Capital}

Figure 5 shows under two large causal loops (HC1 and $\mathrm{HC} 2)$ the causal relationships between the $\mathrm{HC}$ elements. $\mathrm{HC} 1$ begins with the availability of $\mathrm{HC}$ critical mass (conditioned in turn by EC-HC1). In each local context, this critical mass will be made up of people with different personal characteristics (gender, age) that have been shown to explain HC accumulation (education/experience) and competencies [78,92]. The appearance of the figure of the entrepreneur or key person, conditioned by their orientation to entrepreneurship, depends on the accumulation of HC through formal (education) and informal (experience) channels, which in turn condition the presence of certain skills and competencies [22,89,93-97] and depends on personal characteristics (gender, age) [22,78,93,97]. The development of entrepreneurial initiatives or RET by these key people contributes to SRD and thus to the improvement of $\mathrm{HC}[80]$.

The HC2 causal-loop integrates the previous one (HC1) but establishes migration as a starting point that can negatively (emigration) or positively (immigration) impact the critical mass of human capital in a given local context [98]. It also affects their sociodemographic characterization, highlighting the ageing of the population, associated with retirees who return to rural areas [16]. Furthermore, immigration has been related to numerous positive effects on the different factors included in the HC sphere: HC accumulation $[19,86]$, competencies and skills [86], motivations [59] and entrepreneurial orientation [86].

Among the relationships that lead to other capital spheres, these are highlighted:

- HC-SC1: Immigration contributes to the construction of bridging SC, since immigrants rely on their extra-local relationships to build their collaborative networks $[83,98]$.

- HC-SC2: Motivations and expectations (expected social, economic or environmental effects) condition the social acceptance of entrepreneurship and RET in rural areas [70,81,99-102].

- HC-SC3: Personal characteristics (gender, age) determine SC factors such as trust, capacity for cooperation or place attachment [63]. 
- HC-SC4: Population structure and ageing populations can limit service delivery [79].

- HC-PC1: Population structure and ageing populations can limit the provision of infrastructure [79].

- HC-EC1: The accumulation of formal (education) and informal (experience) HC influences the rates of new business creation [103] and their survival [78] and success [104]. Lee and Cowling [94] point out that companies that require skilled labor are less likely to locate in rural areas.

- HC-EC2: Self-employment is conditioned by entrepreneurial orientation, which in turn depends on $\mathrm{HC}$ accumulation, personal characteristics or immigration.

- HC-EC3: Innovation depends on creativity [61,105].

- HC-EC4: Entrepreneurial risk is affected by entrepreneurial orientation and its specific conditions (personal characteristics, HC accumulation).

- HC-EC5: Immigration contributes to the increase of critical mass and reinforces the local demand for products and services [19].

- HC-EC6: Local, social or lifestyle motivation/orientation contributes to greater local embeddedness of business initiatives $[17,85,95,106]$.

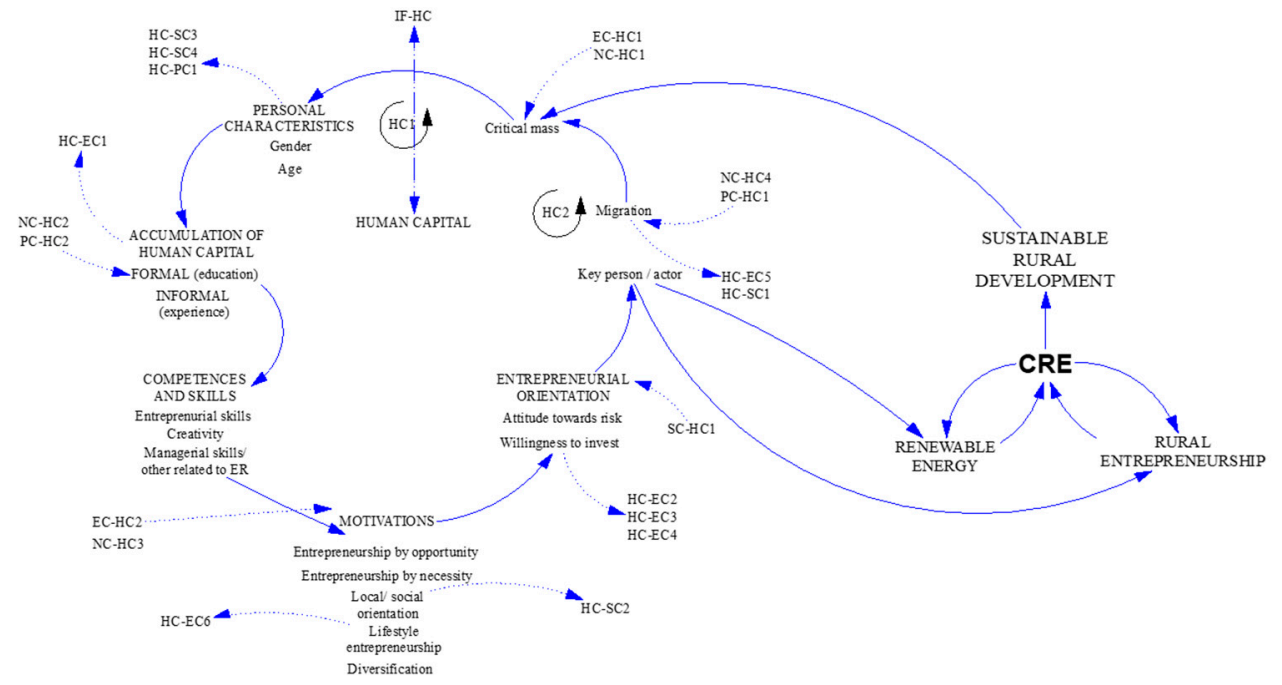

Figure 5. Causal relationships in the HC sphere.

\subsubsection{Social Capital}

Figure 6 shows under a single causal-loop (SC1) the causal relationships between the SC elements. In the first place, the factors considered as antecedents of the SC (role of local governments, families, role models, existence of social services, customs and lifestyles, and cultural and historical heritage), contribute to the configuration of the concept of place [85], and this conditions, together with personal characteristics ( $\mathrm{HC}$ SC3), the block of SC elements formed by interpersonal and institutional trust $[107,108]$, social norms $[29,107]$, cooperation in networks, alliances or clusters $[34,54,84]$ or attitudes towards cooperative movements [109], and place attachment [107,108,110]. The three types of social capital (bonding, bridging and linking), are derived from the combination in different degrees of the SC elements (trust, networks, social norms and place attachment). Networks and clusters can involve the establishment of relationships with government agencies, universities and research centres and other networks (business, knowledge, social) of local or extra-local scope [64]. Trust, place attachment and social norms can condition greater or lesser openness towards collaboration with extra-local networks. Jobert et al. [102] recognize the need for a local support network that conforms to the concept of bonding capital. Von Bock und Polach et al. [14] recognize the importance of bonding and bridging SC for CRE projects. Studies such as those by Kalbrenner and Roosen [107], von Bock und Polach [14] or Wustenhagen et al. [108] establish a direct relationship between SC elements and types and social acceptance, which in turn is a 
prerequisite for involvement and commitment to entrepreneurship, RET or CRE projects. This commitment also depends directly on the institutional level (IF) since it requires participatory processes in the financing of community projects. Entrepreneurial and RET initiatives contribute to rural development and reinforce SC [80].

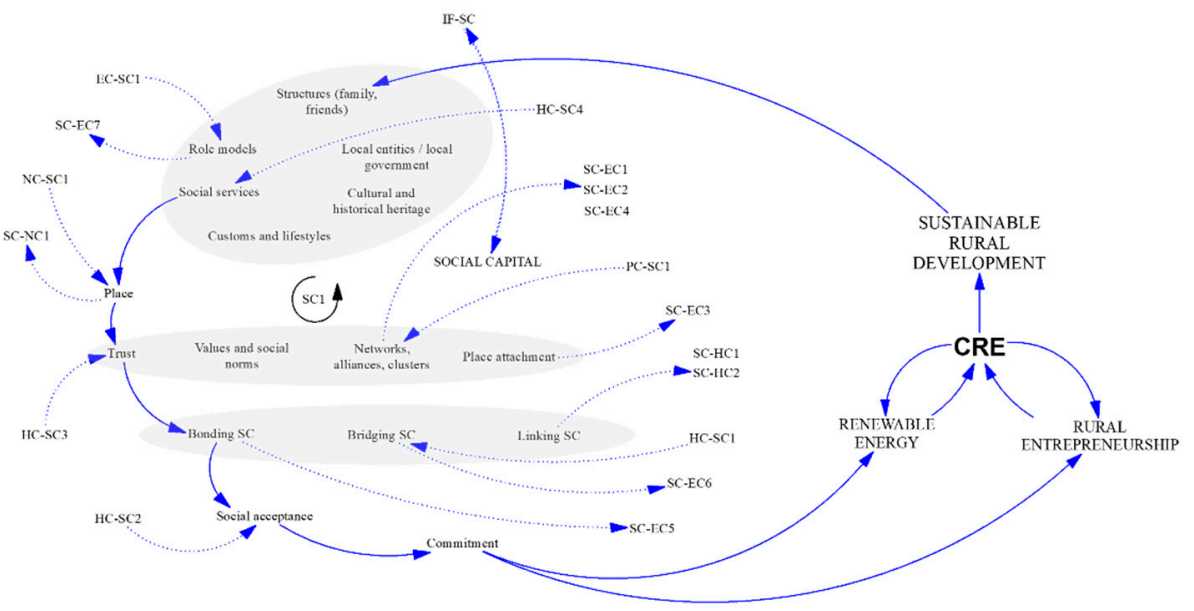

Figure 6. Causal relationships in the SC sphere.

We also highlight these relationships between the SC factors and the other spheres of capital:

- SC-EC1: SC, concerning the presence of alliances and clusters, has a relevant impact on the launch of new entrepreneurial business initiatives [103] or the diversification of traditional agricultural activity [88].

- SC-EC2: Innovation in rural SMEs benefits from the existence of knowledge networks [60] and public-private collaborations [1], and the adoption of RET also depends on the transfer of knowledge to enhance the R\&D\&I capacity of SMEs [91].

- SC-EC3: Place attachment conditions the local embeddedness of entrepreneurial projects [107,110,111]. Korsgaard et al. [85] develop the concept of 'placial embeddedness' to represent the knowledge and use that entrepreneurs make of their physical, cultural and historical environment and their concern for local development. This is also related to the distinction between 'entrepreneurship in the rural' and RE [20].

- SC-EC4: Social capital related to cooperative or network work (networking) has a relevant impact on the risk of new entrepreneurial business initiatives [34,76,95,112].

- SC-EC5: The bonding SC related to networking has a relevant impact on access to local markets [112] and, consequently, on local embeddedness.

- SC-EC6: The bridging SC related to networking has a relevant impact on access to extra-local markets [84,113], depends on immigration $[83,98]$, and combined with local embeddedness can foster the success of entrepreneurial activities [43,84,98].

- SC-EC7: Following Haapanen and Tervo [78] and Goetz and Rupasingha [22], the initial quota of self-employment of a municipality predicts growth in self-employment, since people in self-employment are role models. Connects to EC-SC1.

- SC-HC1: Bonding, bridging and linking SC ties, particularly when they converge in a community or mutualization initiative [114], contribute to reducing the perception of risk and underpinning the entrepreneurial orientation, connecting with HC-EC4.

- SC-HC2: Bonding, bridging and linking SC ties, derived from the combination of SC elements (trust, social norms, networks and place attachment) condition the motivation to start entrepreneurial projects $[112,115,116]$. Regarding CRE, the distinction between place-based communities (related more to bonding capital) or communities of interests (related more to bridging capital) is a clear example of this. Among the SC elements, place attachment, for example, can induce local entrepreneurship to promote local development [92]. 
- $\quad$ SC-NC1: The concept of place, together with that of space, as defined by Korsgaard et al. [85], configure the countryside capital concept as defined by Garrod et al. [41].

\subsubsection{Natural Capital}

Figure 7 shows four main causal-loops that collect the causal relationships between the NC elements. NC1 reflects that the geographical location of rural areas, traditionally associated with the concepts of isolation and remoteness, is linked to assuming that distance is an obstacle to their socioeconomic development $[17,18,64]$. However, an adequate provision of infrastructure (especially telecommunications networks and transport networks), modifies this perception and contributes to counteract this negative conception of the geographical location of rural areas. On the other hand, NC2 states that geographic location conditions the set of natural resources and available environmental or ecosystem services, the proper conservation of which is based on the provision of infrastructure (PC-NC2). This set of resources and services, together with infrastructure (PC-NC1), make up the concept of space used by Korsgaard et al. [85], which in turn is integrated into that of countryside capital along with that of place, as shown in SC-NC1. Countryside capital connects with EC, HC and SC, contributing to SRD, which in turn feeds back to NC, thus closing this causal-loop.

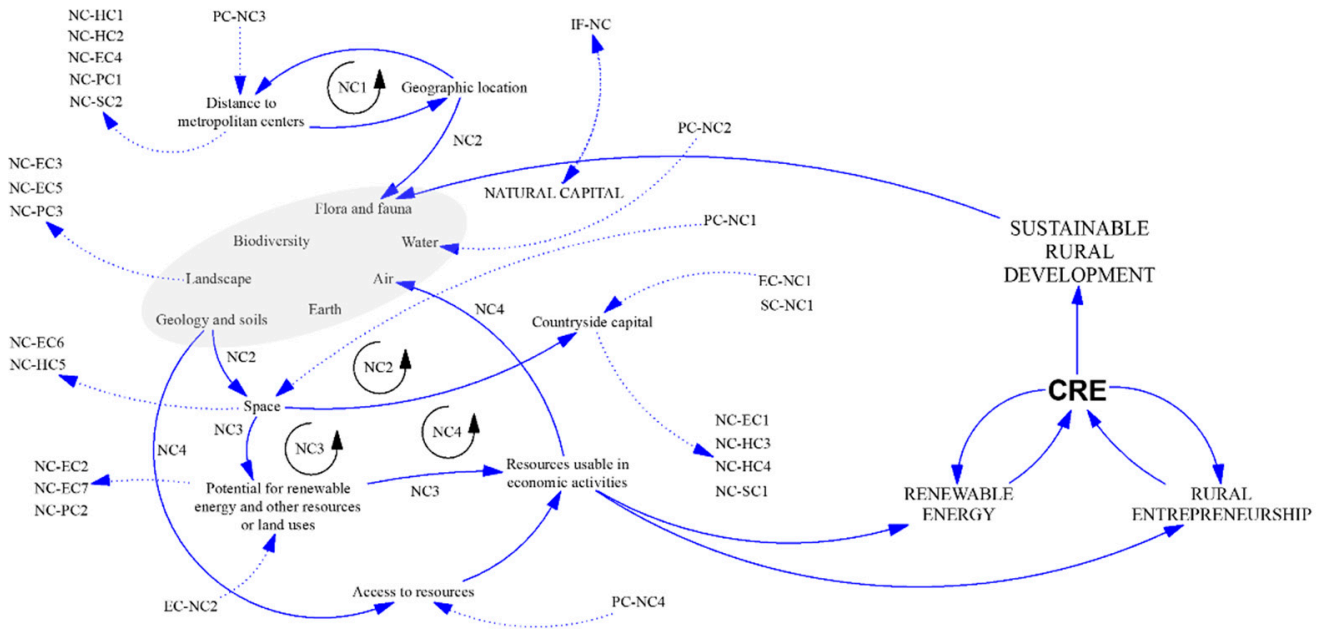

Figure 7. Causal relationships in the NC sphere.

From the concept of space in NC2, the NC3 causal-loop reflects the potential use of the natural resources available in that space (e.g., the existence of wind does not imply that it is sufficient for its use by wind energy). Technological and innovation support are required to guarantee good use of resources (EC-NC2), and the existence of technical potential can, in turn, promote the development of local technological and innovative business (NC-EC2), in addition to supporting the economic feasibility of projects (NC-EC7). However, the existence of exploitable potential also requires the acquisition of access rights to resources, which are derived from the institutional sphere (IF). If, in addition to the technical potential, there is access to resources (access to land, renewable resources, etc.), it will be possible to take advantage of these resources in the development of economic activities.

Access to natural resources for their exploitation also depends on the potential impacts on these and other natural resources (NC4). RET projects (and other types) of a certain size must pass an environmental impact assessment to be carried out [16,81]. These evaluations could also be extended to other areas (economic, social, etc.) to analyze the impact of CRE projects on local sustainability before starting them, thus helping to promote a better design [12].

Among the impacts on other spheres, it is possible to highlight: 
- NC-SC1: All the assets and natural resources that make up the countryside capital, together with the social assets that also form it (cultural and historical heritage, customs and ways of life), are part of the concept of place [85].

- NC-SC2: Geographic location, associated with distance, limits the potential for the development of networks, alliances and clusters $[17,84]$ and the transfer of knowledge [95].

- NC-HC1: Geographic location, related to distance or remote location of many rural areas, limits the availability of critical mass of HC [85].

- NC-HC2: The HC accumulation process is conditioned by geographic locationdistance (the need to leave the rural area to acquire knowledge and experience, risk of not recovering that $\mathrm{HC}$ ) [19].

- NC-HC3: All the assets and resources that make up the countryside capital can be the basis of the motivation to undertake or adopt RET [117] and the expectations associated with it, which in turn conditions its social acceptance, for example, in the case of RET projects, due to the visual effects on landscapes $[99,102,118]$. Connects with HC-SC2.

- NC-HC4: All the assets and resources that form countryside capital can be the basis of migratory movements to rural areas [117].

- NC-HC5: Geographic location, linked to the concept of space $[20,85]$ affects creativity (and this affects innovation capacity through HC-EC4) [61].

- NC-EC1: A direct relationship is established between the concept of countryside capital and rural economic development, assuming that the former is a form of capital in which it is possible to invest and from which an income stream can be obtained [41]. This is a base on which to build rural development that includes traditional agricultural activity and other productive, non-productive and post-productive uses of resources [117]. The availability of natural resources can attract companies that need them to develop their activity [94]. This includes the availability of land for industrial development [27].

- NC-EC2: The availability of RET potential conditions the local technological development of RET [10,119].

- NC-EC3: The availability of inputs and other natural services (i.e., to attract rural tourism) implies the possibility of increasing economic activity in the extra-local sphere $[22,43,96,106]$.

- NC-EC4: Geographic location linked to the concept of distance affects the possibility of connecting with extra-local markets $[17,84,86]$.

- NC-EC5: The availability of inputs (potential for RET, land and other raw materials) facilitates the local embeddedness of projects $[13,27,90,120]$.

- NC-EC6: Geographic location linked to the concept of space affects the availability of financing sources [85]. Rural areas have experienced a dramatic drop in the network of bank branches [121].

- NC-EC7: The technical potential for the use of natural resources conditions the economic feasibility of business initiatives associated with their exploitation.

- NC-PC1: The rural location entails implicit limitations or added difficulties in the provision of infrastructure [106]. Distance, for example, requires the strengthening of telecommunications and broadband internet infrastructures [27], or the transport network.

- NC-PC2: The availability of resources can facilitate the provision of infrastructure. For example, McGuire et al. [122] suggest the use of RET in the equipment necessary to provide broadband internet access in rural areas.

- NC-PC3: The endowment of infrastructure can also be limited by the possible negative impacts on NC elements. 


\subsubsection{Physical Capital}

Figure 8 includes a single causal-loop (PC1) that shows how the provision of infrastructure contributes to the implementation of entrepreneurial initiatives and SRD [123], which in turn has an impact on the improvement of infrastructure. The development of RET also promotes the expansion of the small-scale power generation and supply infrastructure through decentralized or distributed generation models [8,9], which in turn contribute to greater energy security (PC-EC4). This decentralized model reinforces the positive contribution of RET to SRD [14].

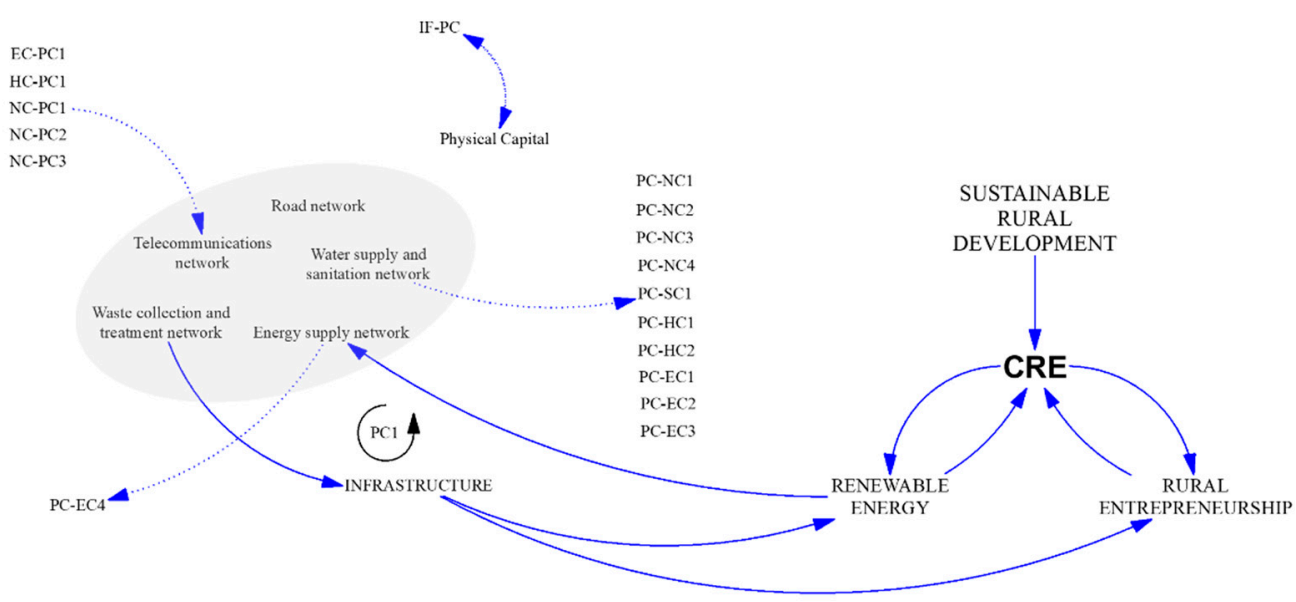

Figure 8. Causal relationships in the PC sphere.

Among the impacts on other spheres, the following are highlighted:

- $\quad$ PC-NC1: Infrastructure configures the concept of space [85] integrated under the broader concept of countryside capital [41]. This connects with NC-SC1 to configure the concept of place [85].

- PC-NC2: Infrastructure contributes to the maintenance and conservation of countryside capital and the provision of ecosystem services such as the preservation of biodiversity, air and water quality, the reinforcement of resilience to floods or fires, and the maintenance of landscape values [123]

- PC-NC3: The availability of infrastructure, such as the road network, moderates the negative impact of location (distance) on other factors included in other spheres of capital [97]. This connects with NC-SC2 (better infrastructure contributes to reducing the negative impact of distance, reinforcing the bridging SC) and in turn conditions the possibility of developing open innovation approaches [84], through the relationship SCEC2. A good road network also facilitates access to extra-local markets, overcoming the obstacle of distance [120] in the NC-EC4 relationship.

- PC-NC4: Access to natural resources may require investment in infrastructure, e.g., the construction of a wind farm requires the construction of access roads [124].

- PC-SC1: Infrastructure, in particular ICTs, can affect the possibility of establishing alliances or collaborative relationships, especially of an extra-local nature, and can take advantage, for example, of spillovers from universities [96].

- PC-HC1: Infrastructure can affect migration to rural areas. Access to the internet or a good transport network is causing the displacement of the workforce to rural areas (telecommuting, living in rural areas and travelling to the city to work) [40].

- PC-HC2: Infrastructures can favor or slow down the HC accumulation process. Internet access is especially important in this regard [125].

- PC-EC1: Improving infrastructure, such as the road network, is critical to improving economic activity $[27,126]$. Socio-economic development can be facilitated and accelerated through the existence of adequate infrastructure [123]. 
- PC-EC2: For Forbord et al. [90], adequate infrastructure is required throughout the supply chain for the development of new bioenergy businesses.

- PC-EC3: The availability and degree of development of infrastructure conditions knowledge-based companies' location decision and affects, therefore, the innovation capacity of a territory [92].

- PC-EC4: Decentralization of energy supply through small-scale infrastructure contributes to greater energy security.

\section{Discussion}

The antecedents or determining factors of CRE can reside within any of the five traditional forms of capital in rural territories: NC (ecosystem services and RET potential), PC (infrastructure), SC (trust, cooperation, networks, social services, place attachment), HC (skills, entrepreneurial orientation, population structure) and EC (rate and quality of employment, economic structure, population change, business creation or financial resources). These factors interact with each other not only within their sphere of capital but also between spheres. Some factors may have a greater potential to drive CRE due to a greater number of connections or interrelations with other factors. Adequate management of the antecedents of CRE in the five spheres of capital will facilitate its positive contribution to SRD, thus creating a virtuous circle associated with the impacts of SRD on the factors that condition the development of rural CRE.

The recognition of these interrelations implies that there are no generic formulas valid for each local context [127] and that it is not possible to act from a single sphere of capital, running the risk of generating influences from another sphere that counteract or limit the effectiveness of the proposed policies and strategies. For example, instead of proposing policies aimed at transferring innovative knowledge to rural areas that cannot absorb these innovations, the proposed map of causal relationships between factors and capital spheres makes it possible to identify other elements on which it may make more sense to act, such as creativity, the ability to participate in networks and clusters, or the promotion of local entrepreneurship [96].

On the other hand, it should not be taken for granted that community participation in the design, implementation, or ownership of CRE projects leads to their social acceptance. Attention should be paid to how ideas and sensitivities around the concept of place can generate different responses in each individual in the community [110], or how social norms and trust condition the various elements of their entrepreneurial orientation and, ultimately, their willingness to participate or invest [107].

The map of cause-effect relationships developed around CRE also helps to identify those factors with the greatest potential to drive its development (those that have more interrelationships with other factors within the same or other spheres), as well as the factors that can generate a multiplicative or exponential impact, as is the case with immigration, a phenomenon to which the literature on RE has paid special attention. It is revealed both as an antecedent and as a consequence of entrepreneurship, insofar as immigrants stimulate local entrepreneurial activity, generating a revitalization of the local economy that attracts new immigrants.

The promotion of a certain factor within a certain capital sphere may be less effective and efficient than acting on another, with induced effects on many other factors in the same sphere of capital or others. From the institutional level, a multilateral and participatory approach should be promoted, involving communities in managing the interrelationships more effectively between factors (for example, managing possible conflicts between land uses when RET enters into competition with other alternatives).

The work of Forbord et al. [90] is a good example of how various factors must be interrelated from different spheres of capital to enable business activity. They conclude that the development of new bioenergy businesses depends on the following conditions: (1) that there is an energy demand (included in the EC sphere in this study); (2) that there is a resource base for bioenergy production (NC sphere); (3) that adequate technologies, 
infrastructures and skills are available throughout the value chain (EC, PC and HC); (4) that there are entrepreneurs interested in starting a business (key person in the field of HC); and (5) that the price of other energy sources is not too low (which conditions demand and economic viability in the EC sphere). They also recognize that institutional factors (financial support and participation of local government) can positively or negatively affect any of these five conditions.

Finally, the development of CRE in rural areas can also promote the expansion of RET and RE under a balanced endogenous development model that takes advantage of and rationalizes the management of local resources. This creates a virtuous circle that contributes to the creation of the rural eco-economy concept conceived by Kitchen and Marsden [3]. As suggested by Graziano et al. [5], economic policies are required to create an impact both on the supply side (stimuli for financing entrepreneurial, RET and CRE initiatives, and processes to promote community participation in their design and development) and on the demand side (strategies for the development of a social and business fabric in rural areas that support the viability of the initiatives and guarantee local energy demand). Public policies must also acknowledge the fundamental role of RE for $\mathrm{SRD}$, in terms of curbing depopulation, maintaining services, avoiding emissions associated with travelling to other areas to work or to access resources and services, maintaining local traditions and customs, or strengthening social capital [18].

A careful evaluation of sectoral policies to avoid supporting economic activities unrelated to rural resources is needed [40], involving actors at the local level to increase their effectiveness and efficiency [128]. Surprisingly, rural areas have not been traditionally considered in energy planning [129], and in the climate change plans of many European regions, the reference to rural areas is mainly related to farming activities [130], without taking into account the potential role of RET to drive SRD. Despite acknowledging that renewables can be crucial for SRD [131], a recent EU audit concludes that their synergies remain largely unrealized [132]. Clausen and Rudolph [133] point out that the political underpinnings of RET planning and development are primarily motivated by the decarbonization of the energy sector, rather than responding to SRD ambitions. CRE are an opportunity to link entrepreneurship, RET and SRD through suitable policy support.

\section{Conclusions}

Although some previous studies in the field of entrepreneurship and RE in rural areas have already highlighted the importance of taking into account factors belonging to different spheres of capital [40-45,134], few have formalized this in the CRE field.

The SLR on RET and RE in the rural context of developed countries has made it possible to draw up a complete framework of the resources, assets and capabilities (belonging to the five capital spheres studied) that could support the successful implementation of CRE in rural areas. Based on this review, we have also been able to generate conceptual maps of the interrelations between these factors, which allow us to acquire a holistic vision of the creation and development processes of rural CRE, recognizing that coordinated actions are required in the different spheres. Decisive support from the institutional sphere is also needed to make these processes effective. In this way, we provide a conceptual framework that helps to understand that any external intervention in a rural community must be analyzed comprehensively and with a broad vision, considering multiple perspectives [45]. In short, by identifying the factors that can condition the development of CRE in different capital spheres, we help to highlight how these initiatives can be supported by the diversity of economic, social, natural, human and physical resources available in a local context. The conceptual maps designed can be used to detect the main resource gaps in each sphere and navigate between their interrelationships to contribute to the achievement of an SRD.

CRE promoters must be aware that the success of these initiatives depends on the inclusive and proactive management of the different elements included under the five capital spheres and the institutional sphere. Actions to promote CRE should be based on an ex-ante and ex-post analysis of the situation in each local context under each sphere. 
New CRE projects should be promoted where there is a set of conditions related to the different capitals (demand for energy, right technologies, infrastructure and competence available throughout the value chain, and entrepreneurs interested in starting projects). Promoters should also analyze the impacts (positive or negative) that could derive from the implementation of rural CRE projects and communicate them appropriately to achieve the participation of community members. On their part, policymakers must recognize the importance of designing integrated policy packages that combine different approaches (territorial, sectoral, etc.) in different spheres of action. Economic policies must address both the supply side and the demand side since they need each other.

The main limitation of this study resides in the identification of factors from the SLR. Pato and Teixeira [51] warn us about SRLs' limitations regarding the chosen search terms since it is practically impossible to analyze all the relevant scientific knowledge with just a few keywords. However, SLRs serve to capture the main scientific articles published in a research area. This study offers a complete and integrated conceptual map that can facilitate the orientation of future research towards the analysis of the causal relationships between specific factors in any of the five capitals considered and CRE, as well as the interrelationships between factors located in different capital spheres.

Author Contributions: Conceptualization, N.R.-C., V.M.-V. and M.Á.L.-C.; methodology, N.R.-C., V.M.-V. and M.Á.L.-C.; software, N.R.-C., V.M.-V. and M.Á.L.-C.; validation, N.R.-C., V.M.-V. and M.Á.L.-C.; formal analysis, N.R.-C.,V.M.-V. and M.Á.L.-C.; writing-original draft preparation, N.R.C., V.M.-V. and M.Á.L.-C.; writing-review and editing, N.R.-C., V.M.-V. and M.Á.L.-C. All authors have read and agreed to the published version of the manuscript.

Funding: This research received no external funding.

Institutional Review Board Statement: Not applicable.

Informed Consent Statement: Not applicable.

Data Availability Statement: Not applicable.

Conflicts of Interest: The authors declare no conflict of interest.

\section{Appendix A}

References included in the SLR, after filtering and snowballing, are listed in the following table.

\begin{tabular}{c} 
Research Field $\quad$ References \\
\hline Akella y Das, 2017; Alvial-Palavicino et al., 2011; Angelis-Dimakis et al., 2011; Bamberg \\
et al., 2015; Barbour et al., 2018; Batel et al., 2013; Bauwens, 2016; Bauwens y \\
Devine-Wright, 2018; Beery y Day, 2015; Bere et al., 2017; Boon y Dieperink, 2014; Busch y \\
McCormick, 2014; Carreño-Ortega et al., 2017; Cloke et al., 2017; D'Souza y Yiridoe, 2014; \\
Dammers y Keiner, 2006; Darbas et al., 2011; Devine-Wright, 2011; Ding et al., 2015; Dombi \\
et al., 2014; Fergen y Jacquet, 2016; Feron et al., 2016, 2017; Forbord et al., 2012; Fuchs y \\
Hinderer, 2014; Gadenne et al., 2011; González et al., 2016; Graziano et al., 2017; Groth y \\
Vogt, 2014; Haggett y Aitken, 2015; Heaslip et al., 2016; Hicks y Ison, 2011; Hoffman y \\
High-Pippert, 2010; Holstead et al., 2017; Janhunen et al., 2014; Jordao, 2010; Kalkbrenner y \\
Roosen, 2016; Karlsson et al., 2017; Katsaprakakis y Christakis, 2016; Kaygusuz, 2007; \\
Kulcsar et al., 2016; Lennon y Scott, 2017; Li et al., 2009; Loomis et al., 2016; Magnani et al., \\
2017; Marinakis et al., 2017; Martinat y Tureckova, 2016; Mattes et al., 2015; McCarthy, 2015; \\
Monteleone et al., 2018; Morrison et al., 2017; Moschidis y Arabatzis, 2013; Moula et al., \\
2013; Nadaï et al., 2015; Newman et al., 2017; Prados, 2010; Rahmann et al., 2016; Ramsey \\
et al., 2013; Rizzo, 2017; Rogers et al., 2012; Rogers et al., 2008; Romich y Bowen-Ellzey, \\
2013; Sauter y Watson, 2007; Scotti y Minervini, 2016; Seyfang et al.,, 2013; Sgroi et al.,, 2018; \\
Shamsuzzoha et al., 2012; Silk et al., 2014; Sliz-Szkliniarz, 2013; Süsser y Kannen, 2017; \\
Tyler y Degoey, 1995; Urmee y Md, 2016; van der Horst, 2008; van der Schoor y Scholtens, \\
2015; van Veelen y Haggett, 2017; Van Vugt, 2001, 2002; von Bock und Polach et al., 2015; \\
Walker et al., 2007, 2010; Walker y Devine-Wright, 2008; Winkler et al., 2017; Wolsink, 2007; \\
Wüste y Schmuck, 2012; Wüstenhagen et al., 2007; Yildiz et al., 2015
\end{tabular}




\begin{tabular}{c} 
Research Field \\
\hline Agarwal et al., 2009; Akgün et al., 2010, 2011; Alario Trigueros y Morales Prieto, 2016; \\
Álvarez et al., 2012; Ambrey et al., 2016; Åmo, 2014; Anthopoulou et al., 2017; Avramenko \\
y Silver, 2010; Backman, 2015; Baumgartner et al., 2010, 2013; Bernardino et al., 2016; Besser \\
y Miller, 2010, 2013; Borch et al., 2008; Bosworth, 2009; Bosworth et al., 2011; Cannarella y \\
Piccioni, 2010; Capelleras et al., 2013; Dammers y Keiner, 2006; de Los Ríos-Carmenado \\
et al., 2016; Deakins et al., 2016; Delfmann et al., 2014; Doh et al., 2017; Eimermann, 2016; \\
Eschker et al., 2017; Farja et al., 2017; Ferreira et al., 2016; Fortunato, 2014; Freire-Gibb y \\
Nielsen, 2014; Fuller-Love et al., 2006; Goetz y Rupasingha, 2014; Gretzinger et al., 2018; \\
Haapanen y Tervo, 2009; Hedlund et al., 2017; Henderson y Weiler, 2010; Herslund, 2012; \\
Iversen y Jacobsen, 2016; Jagoda et al., 2016; Korpysa, 2010; Korsgard, Ferguson, et al., \\
2015; Korsgaard, Müller, et al., 2015; Krakowiak-Bal, Ziemianczyk, Wozniak, et al., 2017; \\
Lafuente et al., 2010; Lang et al., 2014; Lee y Cowling, 2014; Lordkipanidze et al., 2005; \\
Lundberg y Fredman, 2012; Magnani et al., 2017; Magnani y Vaona, 2016; Markantoni y \\
Strijker, 2012; Markantoni y Woolvin, 2013; McGranahan et al., 2011; Mecheri y Pelloni, \\
2006; Morris et al., 2017; Morrison et al., 2017; Müller y Korsgaard, 2018; Munkejord, 2017; \\
Murua-Múgica y Eguía- Peña, 2016; North y Smallbone, 2006; Onyx y Leonard, 2010; Pato y \\
Teixeira, 2016; Peredo y Chrisman, 2006; Petridou y Glaveli, 2008; Phelan y Sharpley, 2012; \\
Price Schultz y Jones, 2017; Reidolf, 2016; Sánchez-Oro Sánchez y Fernández Sánchez, 2017; \\
Santos et al., 2016; Sardadvar y Rocha-Akis, 2016; Serarols-Tarrés et al., 2007; Sergaki et al., \\
2015; Silva et al., 2011; Skuras et al., 2005; Smith, 2017; Stephens et al., 2013; Stockdale, 2006; \\
Toledano y Urbano, 2008; Traphagan, 2017; Uribe Toril et al., 2013; Valchovska y Watts, \\
2016; Varga et al., 2016; Vestrum et al., 2017; Walton-Kirkley, 2016; Westlund et al., 2014 \\
\hline
\end{tabular}

\section{References}

1. de Los Ríos-Carmenado, I.; Ortuño, M.; Rivera, M. Private-Public Partnership as a tool to promote entrepreneurship for sustainable development: WWP torrearte experience. Sustainability 2016, 8, 199. [CrossRef]

2. Reddy, A.K.N. A generic Southern perspective on renewable energy. Energy Sustain. Dev. 2002, 6, 74-83. [CrossRef]

3. Kitchen, L.; Marsden, T. Creating sustainable rural development through stimulating the eco-economy: Beyond the eco-economic paradox? Sociol. Rural. 2009, 49, 273-294. [CrossRef]

4. Marinakis, V.; Papadopoulou, A.G.; Psarras, J. Local communities towards a sustainable energy future: Needs and priorities. Int. J. Sustain. Energy 2015, 36, 296-312. [CrossRef]

5. Graziano, M.; Billing, S.L.; Kenter, J.O.; Greenhill, L. A transformational paradigm for marine renewable energy development. Energy Res. Soc. Sci. 2017, 23, 136-147. [CrossRef]

6. Poggi, F.; Firmino, A.; Amado, M. Planning renewable energy in rural areas: Impacts on occupation and land use. Energy 2018, 155, 630-640. [CrossRef]

7. Streimikiene, D.; Baležentis, T.; Kriščiukaitiene, I. Promoting interactions between local climate change mitigation, sustainable energy development, and rural development policies in Lithuania. Energy Policy 2012, 50, 699-710. [CrossRef]

8. Brummer, V. Community energy-benefits and barriers: A comparative literature review of Community Energy in the UK, Germany and the USA, the benefits it provides for society and the barriers it faces. Renew. Sustain. Energy Rev. 2018, 94, 187-196. [CrossRef]

9. Paredes-Sánchez, J.P.; López-Ochoa, L.M.; López-González, L.M.; Las-Heras-Casas, J.; Xiberta-Bernat, J. Energy utilization for distributed thermal production in rural areas: A case study of a self-sustaining system in Spain. Energy Convers. Manag. 2018, 174, 1014-1023. [CrossRef]

10. Van Hoesen, J.; Letendre, S. Evaluating potential renewable energy resources in Poultney, Vermont: A GIS-based approach to supporting rural community energy planning. Renew. Energy 2010, 35, 2114-2122. [CrossRef]

11. Hain, J.J.; Ault, G.W.; Galloway, S.J.; Cruden, A.; McDonald, J.R. Additional renewable energy growth through small-scale community orientated energy policies. Energy Policy 2005, 33, 1199-1212. [CrossRef]

12. Martire, S.; Tuomasjukka, D.; Lindner, M.; Fitzgerald, J.; Castellani, V. Sustainability impact assessment for local energy supplies' development-The case of the alpine area of Lake Como, Italy. Biomass Bioenergy 2015, 83, 60-76. [CrossRef]

13. Zabaniotou, A.; Rovas, D.; Delivand, M.K.; Francavilla, M.; Libutti, A.; Cammerino, R.; Monteleone, M. Conceptual vision of bioenergy sector development in Mediterranean regions based on decentralized thermochemical systems. Sustain. Energy Technol. Assess. 2017, 23, 33-47. [CrossRef]

14. von Bock und Polach, C.; Kunze, C.; Maaß, O.; Grundmann, P. Bioenergy as a socio-technical system: The nexus of rules, social capital and cooperation in the development of bioenergy villages in Germany. Energy Res. Soc. Sci. 2015, 6, 128-135. [CrossRef]

15. Abreu, I.; Nunes, J.M.; Mesias, F.J. Can Rural Development Be Measured? Design and Application of a Synthetic Index to Portuguese Municipalities. Soc. Indic. Res. 2019, 145, 1107-1123. [CrossRef]

16. Dammers, E.; Keiner, M. Rural Development In Europe. Disp-Plan. Rev. 2006, 42, 5-15. [CrossRef]

17. Fortunato, M.W.P. Supporting rural entrepreneurship: A review of conceptual developments from research to practice. Community Dev. 2014, 45, 387-408. [CrossRef]

18. Steiner, A.; Atterton, J. Exploring the contribution of rural enterprises to local resilience. J. Rural Stud. 2015, 40, 30-45. [CrossRef] 
19. Stockdale, A. Migration: Pre-requisite for rural economic regeneration? J. Rural Stud. 2006, 22, 354-366. [CrossRef]

20. Korsgaard, S.; Müller, S.; Wittorff-Tanvig, H. Rural entrepreneurship or entrepreneurship in the rural-Between place and space. Int. J. Entrep. Behav. Res. 2015, 21, 5-26. [CrossRef]

21. Meccheri, N.; Pelloni, G. Rural entrepreneurs and institutional assistance: An empirical study from mountainous Italy. Entrep. Reg. Dev. 2006, 18, 371-392. [CrossRef]

22. Goetz, S.J.; Rupasingha, A. The Determinants of Self-Employment Growth: Insights From County-Level Data, 2000-2009. Econ. Dev. Q. 2014, 28, 42-60. [CrossRef]

23. Mayer, H.; Habersetzer, A.; Meili, R. Rural-urban linkages and sustainable regional development: The role of entrepreneurs in linking peripheries and centers. Sustainability 2016, 8, 745. [CrossRef]

24. Avramenko, A.; Silver, J.A.K. Rural entrepreneurship: Expanding the horizons. Int. J. Entrep. Innov. Manag. 2010, 11, 140-155. [CrossRef]

25. Newbery, R.; Siwale, J.; Henley, A. Rural entrepreneurship theory in the developing and developed world. Int. J. Entrep. Innov. 2017, 18, 3-4. [CrossRef]

26. Valchovska, S.; Watts, G. Interpreting Community-Based Enterprise: A Case Study from Rural Wales. J. Soc. Entrep. 2016, 7 , 211-235. [CrossRef]

27. Fuller-Love, N.; Midmore, P.; Thomas, D.; Henley, A. Entrepreneurship and rural economic development: A scenario analysis approach. Int. J. Entrep. Behav. Res. 2006, 12, 289-305. [CrossRef]

28. Romano, A.A.; Scandurra, G.; Carfora, A.; Fodor, M. Renewable investments: The impact of green policies in developing and developed countries. Renew. Sustain. Energy Rev. 2017, 68, 738-747. [CrossRef]

29. Magnani, N.; Maretti, M.; Salvatore, R.; Scotti, I. Ecopreneurs, rural development and alternative socio-technical arrangements for community renewable energy. J. Rural. Stud. 2017, 52, 33-41. [CrossRef]

30. Roesler, T. Community resources for energy transition: Implementing bioenergy villages in Germany. Area 2019, 51, 268-276. [CrossRef]

31. Becker, S.; Kunze, C.; Vancea, M. Community energy and social entrepreneurship: Addressing purpose, organisation and embeddedness of renewable energy projects. J. Clean. Prod. 2017, 147, 25-36. [CrossRef]

32. Walker, G.; Devine-Wright, P. Community renewable energy: What should it mean? Energy Policy 2008, 36, 497-500. [CrossRef]

33. Boon, F.P.; Dieperink, C. Local civil society based renewable energy organisations in The Netherlands: Exploring the factors that stimulate their emergence and development. Energy Policy 2014, 69, 297-307. [CrossRef]

34. Karlsson, N.P.E.; Halila, F.; Mattsson, M.; Hoveskog, M. Success factors for agricultural biogas production in Sweden: A case study of business model innovation. J. Clean. Prod. 2017, 142, 2925-2934. [CrossRef]

35. Wüste, A.; Schmuck, P. Bioenergy villages and regions in Germany: An interview study with initiators of communal bioenergy projects on the success factors for restructuring the energy supply of the community. Sustainability 2012, 4, 244-256. [CrossRef]

36. Walker, G. What are the barriers and incentives for community-owned means of energy production and use? Energy Policy 2008, 36, 4401-4405. [CrossRef]

37. Hewitt, R.J.; Bradley, N.; Compagnucci, A.B.; Barlagne, C.; Ceglarz, A.; Cremades, R.; McKeen, M.; Otto, I.M.; Slee, B. Social innovation in community energy in Europe: A review of the evidence. Front. Energy Res. 2019, 7, 1-27. [CrossRef]

38. van der Schoor, T.; Scholtens, B. The power of friends and neighbors: A review of community energy research. Curr. Opin. Environ. Sustain. 2019, 39, 71-80. [CrossRef]

39. Li, L.W.; Birmele, J.; Schaich, H.; Konold, W. Transitioning to Community-owned Renewable Energy: Lessons from Germany. Procedia Environ. Sci. 2013, 17, 719-728. [CrossRef]

40. Akgün, A.A.; Baycan-Levent, T.; Nijkamp, P.; Poot, J. Roles of Local and Newcomer Entrepreneurs in Rural Development: A Comparative Meta-analytic Study. Reg. Stud. 2011, 45, 1207-1223. [CrossRef]

41. Garrod, B.; Wornell, R.; Youell, R. Re-conceptualising rural resources as countryside capital: The case of rural tourism. J. Rural. Stud. 2006, 22, 117-128. [CrossRef]

42. Agarwal, S.; Rahman, S.; Errington, A. Measuring the determinants of relative economic performance of rural areas. J. Rural. Stud. 2009, 25, 309-321. [CrossRef]

43. Müller, S.; Korsgaard, S. Resources and bridging: The role of spatial context in rural entrepreneurship. Entrep. Reg. Dev. 2018, 30, 224-255. [CrossRef]

44. Borch, J.; Odd, A.; Førde, L.; Rønning, I.; Vestrum, K.; Alsos, G.A. Resource Configuration and Creative Practices of Community Entrepreneurs. J. Enterprising Communities People Places Glob. Econ. 2008, 2, 100-123. [CrossRef]

45. González, A.M.; Sandoval, H.; Acosta, P.; Henao, F. On the acceptance and sustainability of renewable energy projects-a systems thinking perspective. Sustainability 2016, 8, 1171. [CrossRef]

46. Helm, D. Natural capital: Assets, systems, and policies. Oxf. Rev. Econ. Policy 2019, 35, 1-13. [CrossRef]

47. Cook, D.J.; Greengold, N.L.; Ellrodt, A.G.; Weingarten, S.R. The relation between systematic reviews and practice guidelines: Sistema de descoberta para FCCN. Acad. Clin. 1997, 127, 210-216.

48. Annarelli, A.; Battistella, C.; Nonino, F. Product service system: A conceptual framework from a systematic review. J. Clean. Prod. 2016, 139, 1011-1032. [CrossRef]

49. Reim, W.; Parida, V.; Örtqvist, D. Product-Service Systems (PSS) business models and tactics-A systematic literature review. J. Clean. Prod. 2015, 97, 61-75. [CrossRef] 
50. Adriaanse, L.S.; Rensleigh, C. Web of science, scopus and google scholar a content comprehensiveness comparison. Electron. Libr. 2013, 31, 727-744. [CrossRef]

51. Pato, M.L.; Teixeira, A.A.C. Twenty Years of Rural Entrepreneurship: A Bibliometric Survey. Sociol. Rural. 2016, 56, 3-28. [CrossRef]

52. Sterman, J. Business Dynamics_Systems Thinking and Modelling for a Complex World; McGraw-Hill Companies, Inc.: New York, NY, USA, 2000.

53. Rehman, J.; Sohaib, O.; Asif, M.; Pradhan, B. Applying systems thinking to flood disaster management for a sustainable development. Int. J. Disaster Risk Reduct. 2019, 36, 101101. [CrossRef]

54. Deakins, D.; Bensemann, J.; Battisti, M. Entrepreneurial skill and regulation: Evidence from primary sector rural entrepreneurs. Int. J. Entrep. Behav. Res. 2016, 22, 234-259. [CrossRef]

55. Serarols-Tarrés, C.; Urbano, D.; Vaillant, Y. Support systems for new enterprise formation in Catalonia: An institutional approach. Int. J. Bus. Syst. Res. 2007, 1, 257-279. [CrossRef]

56. Bauwens, T.; Devine-Wright, P. Positive energies? An empirical study of community energy participation and attitudes to renewable energy. Energy Policy 2018, 118, 612-625. [CrossRef]

57. Lordkipanidze, M.; Brezet, H.; Backman, M. The entrepreneurship factor in sustainable tourism development. J. Clean. Prod. 2005, 13, 787-798. [CrossRef]

58. Doh, K.; Park, S.; Kim, D.Y. Antecedents and consequences of managerial behavior in agritourism. Tour. Manag. 2017, 61, 511-522. [CrossRef]

59. Iversen, I.; Jacobsen, J.K.S. Migrant Tourism Entrepreneurs in Rural Norway. Scand. J. Hosp. Tour. 2016, 16, 484-499. [CrossRef]

60. Reidolf, M. Knowledge networks and the nature of knowledge relationships of innovative rural SMEs. Eur. J. Innov. Manag. 2016, 19, 317-336. [CrossRef]

61. Price Schultz, C.J.; Jones, M. You Can't Do That! A Case Study of Rural and Urban Media Entrepreneur Experience. JMM Int. J. Media Manag. 2017, 19, 11-28. [CrossRef]

62. Sánchez-Oro Sánchez, M.; Fernández Sánchez, M.R. Tecnologías digitales y emprendimiento de mujeres rurales. Cuid. Digit. 2017, 18, 259-277.

63. Romich, E.; Bowen-Ellzey, N. Growing Community Capacity in Energy Development through Extension Education. J. Ext. 2013, 51. Available online: https://tigerprints.clemson.edu/joe/vol51/iss3/7/ (accessed on 18 January 2022).

64. Jagoda, K.; Lin, X.; Calvert, V.; Tao, S. Accountability of venture support agencies: Do they really help? Entrep. Res. J. 2016, 6, 175-206. [CrossRef]

65. Li, L.; Kang, K.; Sohaib, O. Investigating factors affecting Chinese tertiary students' online-startup motivation based on the COM-B behaviour changing theory. J. Entrep. Emerg. Econ. 2021. [CrossRef]

66. Monteleone, M.; Cammerino, A.R.B.; Libutti, A. Agricultural "greening" and cropland diversification trends: Potential contribution of agroenergy crops in Capitanata (South Italy). Land Use Policy 2018, 70, 591-600. [CrossRef]

67. Prados, M.J. Renewable energy policy and landscape management in Andalusia, Spain: The facts. Energy Policy 2010, 38, 6900-6909. [CrossRef]

68. Starick, A.; Syrbe, R.U.; Steinhäußer, R.; Lupp, G.; Matzdorf, B.; Zander, P. Scenarios of bioenergy provision: Technological developments in a landscape context and their social effects. Environ. Dev. Sustain. 2014, 16, 575-594. [CrossRef]

69. Dombi, M.; Kuti, I.; Balogh, P. Sustainability assessment of renewable power and heat generation technologies. Energy Policy 2014, 67, 264-271. [CrossRef]

70. Janhunen, S.; Hujala, M.; Pätäri, S. Owners of second homes, locals and their attitudes towards future rural wind farm. Energy Policy 2014, 73, 450-460. [CrossRef]

71. Cloke, J.; Mohr, A.; Brown, E. Imagining renewable energy: Towards a Social Energy Systems approach to community renewable energy projects in the Global South. Energy Res. Soc. Sci. 2017, 31, 263-272. [CrossRef]

72. Beery, J.A.; Day, J.E. Community investment in wind farms: Funding structure effects in wind energy infrastructure development. Environ. Sci. Technol. 2015, 49, 2648-2655. [CrossRef]

73. Munday, M.; Bristow, G.; Cowell, R. Wind farms in rural areas: How far do community benefits from wind farms represent a local economic development opportunity? J. Rural. Stud. 2011, 27, 1-12. [CrossRef]

74. Okkonen, L.; Lehtonen, O. Socio-economic impacts of community wind power projects in Northern Scotland. Renew. Energy 2016, 85, 826-833. [CrossRef]

75. Slee, B. Is there a case for community-based equity participation in Scottish on-shore wind energy production? Gaps in evidence and research needs. Renew. Sustain. Energy Rev. 2015, 41, 540-549. [CrossRef]

76. Psaltopoulos, D.; Stathopoulou, S.; Skuras, D. The location of markets, perceived entrepreneurial risk, and start-up capital of micro rural firms. Small Bus. Econ. 2005, 25, 147-158. [CrossRef]

77. Korpysa, J. Unemployment as a main determinant of entrepreneurship. Transform. Bus. Econ. 2010, 9, 109-123.

78. Haapanen, M.; Tervo, H. Self-employment duration in urban and rural locations. Appl. Econ. 2009, 41, 2449-2461. [CrossRef]

79. Delfmann, H.; Koster, S.; McCann, P.; Van Dijk, J. Population Change and New Firm Formation in Urban and Rural Regions. Reg. Stud. 2014, 48, 1034-1050. [CrossRef]

80. Berka, A.L.; Creamer, E. Taking stock of the local impacts of community owned renewable energy: A review and research agenda. Renew. Sustain. Energy Rev. 2018, 82, 3400-3419. [CrossRef] 
81. Heaslip, E.; Costello, G.J.; Lohan, J. Assessing Good-practice Frameworks for the Development of Sustainable Energy Communities in Europe: Lessons from Denmark and Ireland. J. Sustain. Dev. Energy Water Environ. Syst. 2016, 4, 307-319. [CrossRef]

82. Warren, C.R.; McFadyen, M. Does community ownership affect public attitudes to wind energy? A case study from south-west Scotland. Land Use Policy 2010, 27, 204-213. [CrossRef]

83. Bosworth, G. Entrepreneurial in-migrants and economic development in rural England. Int. J. Entrep. Small Bus. 2008, 6, 355. [CrossRef]

84. Bosworth, G.; Dana, L.-P.; McElwee, G. EU industrial policy and competitiveness in rural SMEs. Int. J. Entrep. Small Bus. 2011, 14, 391. [CrossRef]

85. Korsgaard, S.; Ferguson, R.; Gaddefors, J. The best of both worlds: How rural entrepreneurs use placial embeddedness and strategic networks to create opportunities. Entrep. Reg. Dev. 2015, 27, 574-598. [CrossRef]

86. Bosworth, G. Education, mobility and rural business development. J. Small Bus. Enterp. Dev. 2009, 16, 660-677. [CrossRef]

87. Holstead, K.L.; Galán-Díaz, C.; Sutherland, L.A. Discourses of on-farm wind energy generation in the UK farming press. J. Environ. Policy Plan. 2017, 19, 391-407. [CrossRef]

88. McElwee, G.; Smith, R. Classifying the strategic capability of farmers: A segmentation framework. Int. J. Entrep. Ventur. 2012, 4, 111-131. [CrossRef]

89. Phelan, C.; Sharpley, R. Exploring entrepreneurial skills and competencies in farm tourism. Local Econ. 2012, 27, 103-118. [CrossRef]

90. Forbord, M.; Vik, J.; Hillring, B.G. Development of local and regional forest based bioenergy in Norway-Supply networks, financial support and political commitment. Biomass Bioenergy 2012, 47, 164-176. [CrossRef]

91. Ramsey, E.; Bond, D.; Hanna, D.; Gallagher, E. Encouraging technology transfer among SMEs in the northern periphery of Europe. Technol. Anal. Strateg. Manag. 2013, 25, 341-353. [CrossRef]

92. Lafuente, E.; Vaillant, Y.; Serarols, C. Location decisions of knowledge-based entrepreneurs: Why some Catalan KISAs choose to be rural? Technovation 2010, 30, 590-600. [CrossRef]

93. Åmo, B.W. Antecedents, prevalence and manifestations of social entrepreneurship. Int. J. Entrep. Ventur. 2014, 6, 162. [CrossRef]

94. Lee, N.; Cowling, M. Do rural firms perceive different problems? Geography, sorting, and barriers to growth in UK SMEs. Environ. Plan. C Gov. Policy 2014, 33, 25-42. [CrossRef]

95. Morrison, C.; Ramsey, E.; Bond, D. The role of social entrepreneurs in developing community resilience in remote areas. J. Enterprising Communities 2017, 11, 95-112. [CrossRef]

96. Stephens, H.M.; Partridge, M.D.; Faggian, A. Innovation, entrepreneurship and economic growth in lagging regions. J. Reg. Sci. 2013, 53, 778-812. [CrossRef]

97. Vaillant, Y.; Lafuente, E. Do different institutional frameworks condition the influence of local fear of failure and entrepreneurial examples over entrepreneurial activity? Entrep. Reg. Dev. 2007, 19, 313-337. [CrossRef]

98. Kalantaridis, C.; Bika, Z. In-migrant entrepreneurship in rural England: Beyond local embeddedness. Entrep. Reg. Dev. 2006, 18, 109-131. [CrossRef]

99. D'Souza, C.; Yiridoe, E.K. Social acceptance of wind energy development and planning in rural communities of Australia: A consumer analysis. Energy Policy 2014, 74, 262-270. [CrossRef]

100. Fergen, J.; Jacquet, J.B. Beauty in motion: Expectations, attitudes, and values of wind energy development in the rural U.S. Energy Res. Soc. Sci. 2016, 11, 133-141. [CrossRef]

101. Groth, T.M.; Vogt, C.A. Rural wind farm development: Social, environmental and economic features important to local residents. Renew. Energy 2014, 63, 1-8. [CrossRef]

102. Jobert, A.; Laborgne, P.; Mimler, S. Local acceptance of wind energy: Factors of success identified in French and German case studies. Energy Policy 2007, 35, 2751-2760. [CrossRef]

103. Westlund, H.; Larsson, J.P.; Olsson, A.R. Start-ups and Local Entrepreneurial Social Capital in the Municipalities of Sweden. Reg. Stud. 2014, 48, 974-994. [CrossRef]

104. Skuras, D.; Meccheri, N.; Moreira, M.B.; Rosell, J.; Stathopoulou, S. Entrepreneurial human capital accumulation and the growth of rural businesses: A four-country survey in mountainous and lagging areas of the European union. J. Rural. Stud. 2005, 21, 67-79. [CrossRef]

105. Gretzinger, S.; Fietze, S.; Brem, A.; Ogbonna, T.U. Small scale entrepreneurship-understanding behaviors of aspiring entrepreneurs in a rural area. Compet. Rev. Int. Bus. J. 2018, 28, 22-42. [CrossRef]

106. Lundberg, C.; Fredman, P. Success factors and constraints among nature-based tourism entrepreneurs. Curr. Issues Tour. 2012, 15, 649-671. [CrossRef]

107. Kalkbrenner, B.J.; Roosen, J. Citizens' willingness to participate in local renewable energy projects: The role of community and trust in Germany. Energy Res. Soc. Sci. 2016, 13, 60-70. [CrossRef]

108. Wüstenhagen, R.; Wolsink, M.; Bürer, M.J. Social acceptance of renewable energy innovation: An introduction to the concept. Energy Policy 2007, 35, 2683-2691. [CrossRef]

109. Bauwens, T. Explaining the diversity of motivations behind community renewable energy. Energy Policy 2016, 93, 278-290. [CrossRef]

110. van Veelen, B.; Haggett, C. Uncommon Ground: The Role of Different Place Attachments in Explaining Community Renewable Energy Projects. Sociol. Rural. 2017, 57, 533-554. [CrossRef] 
111. Lang, R.; Fink, M.; Kibler, E. Understanding place-based entrepreneurship in rural Central Europe: A comparative institutional analysis. Int. Small Bus. J. 2014, 32, 204-227. [CrossRef]

112. Besser, T.L.; Miller, N.J. Community matters: Successful entrepreneurship in remote rural US locations. Int. J. Entrep. Innov. 2013, 14, 15-27. [CrossRef]

113. Müller, S. Entrepreneurship and Regional Development-On the Interplay between Agency and Context. Ph.D. Thesis, Aarhus University, Aarhus, Denmark, 2013.

114. Nadaï, A.; Labussière, O.; Debourdeau, A.; Régnier, Y.; Cointe, B.; Dobigny, L. French policy localism: Surfing on ‘Positive Energie Territories' (Tepos). Energy Policy 2015, 78, 281-291. [CrossRef]

115. Busch, H.; McCormick, K. Local power: Exploring the motivations of mayors and key success factors for local municipalities to go 100\% renewable energy. Energy Sustain. Soc. 2014, 4, 5. [CrossRef]

116. Freire-Gibb, L.C.; Nielsen, K. Entrepreneurship Within Urban and Rural Areas: Creative People and Social Networks. Reg. Stud. 2014, 48, 139-153. [CrossRef]

117. Eimermann, M. Two sides of the same coin: Dutch rural tourism entrepreneurs and countryside capital in Sweden. Rural Soc. 2016, 25, 55-73. [CrossRef]

118. Martinot, E. Renewable energy investment by the World Bank. Energy Policy 2001, 29, 689-699. [CrossRef]

119. Sliz-Szkliniarz, B. Assessment of the renewable energy-mix and land use trade-off at a regional level: A case study for the Kujawsko-Pomorskie Voivodship. Land Use Policy 2013, 35, 257-270. [CrossRef]

120. Kalantaridis, C.; Bika, Z. Local embeddedness and rural entrepreneurship: Case-study evidence from Cumbria, England. Environ. Plan. A 2006, 38, 1561-1579. [CrossRef]

121. Backman, M. Banks and new firm formation. J. Small Bus. Enterp. Dev. 2015, 22, 734-761. [CrossRef]

122. McGuire, C.; Brew, M.R.; Darbari, F.; Bolton, G.; McMahon, A.; Crawford, D.H.; Weiss, S.; Stewart, R.W. HopScotch-a low-power renewable energy base station network for rural broadband access. Eurasip J. Wirel. Commun. Netw. 2012, 2012, 112. [CrossRef]

123. Krakowiak-Bal, A.; Ziemianczyk, U.; Wozniak, A.; Krakowiak-bal, A. Building entrepreneurial capacity in rural areas The use of AHP analysis for infrastructure evaluation. Int. J. Entrep. Behav. Res. 2017, 23, 903-918. [CrossRef]

124. Loomis, D.G.; Hayden, J.; Noll, S.; Payne, J.E. Economic Impact of Wind Energy in Illinois. J. Bus. Valuat. Econ. Loss Anal. 2016, 11, 3-23. [CrossRef]

125. Morris, W.; Henley, A.; Dowell, D. Farm diversification, entrepreneurship and technology adoption: Analysis of upland farmers in Wales. J. Rural. Stud. 2017, 53, 132-143. [CrossRef]

126. North, D.; Smallbone, D. Developing entrepreneurship and enterprise in Europe's peripheral rural areas: Some issues facing policy-makers. Eur. Plan. Stud. 2006, 14, 41-60. [CrossRef]

127. Süsser, D.; Döring, M.; Ratter, B.M.W. Harvesting energy: Place and local entrepreneurship in community-based renewable energy transition. Energy Policy 2017, 101, 332-341. [CrossRef]

128. Neto, P.; Santos, A.; Serrano, M.M. Public policies supporting local networks for entrepreneurship and innovation: Effectiveness and added value analysis of leader program in the Alentejo region of Portugal. Int. J. Entrep. Small Bus. 2014, 21, 406-435. [CrossRef]

129. Poggi, F.; Firmino, A.; Amado, M. Shaping energy transition at municipal scale: A net-zero energy scenario-based approach. Land Use Policy 2020, 99, 104955. [CrossRef]

130. Markantoni, M.; Woolvin, M. The role of rural communities in the transition to a low-carbon Scotland: A review. Local Environ. 2013, 20, 202-219. [CrossRef]

131. OECD. OECD Linking Renewable Energy to Rural Development Executive Summary; OECD Publishing: Paris, France, 2012.

132. ECA. Special Report No. 05. Renewable Energy for Sustainable Rural Development: Significant Potential Synergies, but Mostly Unrealized; European Cout of Auditors (ECA): Luxembourg, 2018.

133. Clausen, L.T.; Rudolph, D. Renewable energy for sustainable rural development: Synergies and mismatches. Energy Policy 2020 138, 111289. [CrossRef]

134. Winkler, B.; Lemke, S.; Ritter, J.; Lewandowski, I. Integrated assessment of renewable energy potential: Approach and application in rural South Africa. Environ. Innov. Soc. Transit. 2017, 24, 17-31. [CrossRef] 